\title{
Preliminary assessment and conservation of insect pollinators through community participation in the Lahaul and Spiti district of Himachal Pradesh, India
}

\author{
Mona Chauhan, V. P. Uniyal*, Agni Chandra, Pooja Thakur and \\ Vandana Mehrwar \\ Wildlife Institute of India, Chandrabani, Dehradun 248 001, India
}

\begin{abstract}
Pollination contributes an enormous economic value to the reproduction of the flowering plants, in the wild and the managed ecosystems of the world. Biotic pollination, particularly from insects is vital to sexual reproduction and genetic diversity of cultivated and wild plants. Disorder in the pollination system and the decline of pollinators are identified as potential consequences of anthropogenic land use change. Land clearance, habitat fragmentation, changing agricultural practices, herbicides, pesticides and the introduction of non-native exotic plants and pollinator species have resulted in pollination crises. Considering the above facts, this study was conducted in the Indian Trans-Himalayan Region (THR). Major Insect pollinators taxa have been selected to identify the important contributors in the pollination services. Conservation awareness programmes, hands on training and knowledge publicity materials were used for sensitization of different stakeholders.
\end{abstract}

Keywords: Climate change, community participation, ecosystem services, insect pollinators, land use.

POLLINATION is one of the pivotal services provided by insects in natural and managed ecosystems. But their population is facing several threats due to land-use changes and unsustainable land-use practices. Land-use changes are said to be one of the most important global issues alongside climate change that will lead to species loss. Loss of species from the community can have cascading effects on the ecosystem. Loss of pollinators will hamper the pollination of unique flora of the Trans Himalayan Region (THR) of India resulting in the loss or reduction of the range of its rare and endemic fauna. The pollinators of THR especially have short life cycles and long hibernation seasons. Global climate changes and land use shift can cause a mismatch between pollinator emergence and floral appearances. Thus, the huge loss of plant reproduction and seed formation affect humans and

\footnotetext{
*For correspondence. (e-mail: uniyalvp@wii.gov.in)
}

wildlife equally. Loss of pollinators will further reduce the reproduction and genetic diversity of the rare Trans Himalayan flowering vegetation, which will in turn affect wildlife and people of the region. The THR has a short agricultural growing season that spans from 3 to 5 months. The loss of mutualists such as pollinators due to floral-faunal mismatch in emergence and habitat loss will adversely affect food production in an already foodscarce region ${ }^{1-3}$. This could lead to increased dependency on imports and deterioration of socio-economic, cultural and traditional structures of the THR which are closely knit with its well-being and conservation.

The THR is also witnessing shift in land-use practices and increasing anthropogenic pressure. Insect pollinators are extremely sensitive to such changes and loss of natural habitats can affect the nesting, foraging and breeding sites of pollinators ${ }^{4-6}$. Thus it is important to assess the impact of climate change and degree of decline in insect pollinator populations at the landscape level. Inclusion and sensitization of all stakeholders (landholders and volunteers, agricultural industry, government and NGOs) is required for effective landscape-level interventions. Considering all these facts, the present study was initiated in Lahaul and Spiti district of Himachal Pradesh. It has been observed that traditional mixed farming is transforming into high-value cash crops in the study area. Homogenization of crops is also increasing due to monoculture practices. Inappropriate use of insecticides and agriculture intensification are also potential threats to the diversity of pollinators in the study area.

Overgrazing of natural habitats can affect the nesting, foraging and breeding sites of the pollinators. This will cause the decline in the pollinator populations, which in turn will result in reduction of plant populations unique to the region. Loss of rare endangered flora will further affect the unique wild herbivores of the region dependent on vegetation. Loss in wilderness and the species associated with it will further affect the productivity of the cultivated plants, which will have a direct impact on the food, nutrition and socio-economic patterns of the THR. 
The study area has been stratified on the basis of elevation, habitat and vegetation types and managed lands to explore the diversity of pollinators along each gradient. Each site has been selected randomly in the various altitudinal categories so that all types of habitats could be sampled more rigorously. Several sampling sites have been selected at each stratum so that comprehensive representation of the diversity at different habitats and fragments largely reflecting the local communities could

Table 1. List of sampling sites in the Lahaul and Spiti district, Himachal Pradesh, India

\begin{tabular}{|c|c|c|}
\hline Location & Latitude & Longitude \\
\hline Mudh & $31^{\circ} 57^{\prime} 29.58$ & $078^{\circ} 01^{\prime} 56.28$ \\
\hline Teling & $31^{\circ} 59^{\prime} 12.22$ & $078^{\circ} 04^{\prime} 30.99$ \\
\hline Sagnam & $32^{\circ} 01^{\prime} 28.58$ & $078^{\circ} 03^{\prime} 24.90$ \\
\hline Jaldu & $32^{\circ} 01^{\prime} 58.69$ & $078^{\circ} 04^{\prime} 19.65$ \\
\hline Tangati & $32^{\circ} 02^{\prime} 30.92$ & $078^{\circ} 06^{\prime} 21.89$ \\
\hline Guling & $32^{\circ} 02^{\prime} 36.76$ & $078^{\circ} 05^{\prime} 24.20$ \\
\hline Kungari & $32^{\circ} 02^{\prime} 42.22$ & $078^{\circ} 04^{\prime} 46.38$ \\
\hline Pin Valley National Park & $32^{\circ} 02^{\prime} 33.14$ & $077^{\circ} 58^{\prime} 31.26$ \\
\hline Poh & $32^{\circ} 03^{\prime} 00.51$ & $078^{\circ} 19^{\prime} 09.35$ \\
\hline Tabo & $32^{\circ} 05^{\prime} 35.17$ & $078^{\circ} 23^{\prime} 09.55$ \\
\hline Kaza & $32^{\circ} 13^{\prime} 22.68$ & $078^{\circ} 04^{\prime} 19.52$ \\
\hline Komic & $32^{\circ} 13^{\prime} 53.71$ & $078^{\circ} 06^{\prime} 31.03$ \\
\hline Hikkim & $32^{\circ} 14^{\prime} 48.63$ & $078^{\circ} 05^{\prime} 32.97$ \\
\hline Kee & $32^{\circ} 17^{\prime} 32.50$ & $078^{\circ} 00^{\prime} 47.76$ \\
\hline Pattan valley-1 & $32^{\circ} 38^{\prime} 23.11$ & $076^{\circ} 52^{\prime} 25.69$ \\
\hline Pattan valley-2 & $32^{\circ} 36^{\prime} 32.41$ & $076^{\circ} 52^{\prime} 48.73$ \\
\hline Pattan valley-3 & $32^{\circ} 43^{\prime} 43.31$ & $076^{\circ} 39^{\prime} 31.23$ \\
\hline Pattan valley-4 & $32^{\circ} 26^{\prime} 01.92$ & $077^{\circ} 11^{\prime} 33.95$ \\
\hline Pattan valley-5 & $32^{\circ} 36^{\prime} 56.84$ & $077^{\circ} 52^{\prime} 46.90$ \\
\hline Miyar valley-1 & $32^{\circ} 44^{\prime} 44.79$ & $076^{\circ} 41^{\prime} 50.85$ \\
\hline Miyar valley-2 & $32^{\circ} 46^{\prime} 05.46$ & $076^{\circ} 42^{\prime} 12.59$ \\
\hline Miyar valley-3 & $32^{\circ} 47^{\prime} 32.28$ & $076^{\circ} 43^{\prime} 09.84$ \\
\hline Miyar valley-4 & $32^{\circ} 49^{\prime} 28.31$ & $076^{\circ} 44^{\prime} 27.33$ \\
\hline Miyar valley-5 & $32^{\circ} 51^{\prime} 16.57$ & $076^{\circ} 47^{\prime} 22.45$ \\
\hline Miyar valley-6 & $32^{\circ} 51^{\prime} 43.57$ & $076^{\circ} 48^{\prime} 55.32$ \\
\hline Miyar valley-7 & $32^{\circ} 52^{\prime} 12.14$ & $076^{\circ} 51^{\prime} 01.90$ \\
\hline Miyar valley-8 & $32^{\circ} 40^{\prime} 50.46$ & $076^{\circ} 41^{\prime} 26.87$ \\
\hline Toth valley & $32^{\circ} 33^{\prime} 46.12$ & $077^{\circ} 03^{\prime} 50.89$ \\
\hline Toth valley & $32^{\circ} 35^{\prime} 26.12$ & $077^{\circ} 07^{\prime} 37.85$ \\
\hline Toth valley & $32^{\circ} 37^{\prime} 33.99$ & $077^{\circ} 09^{\prime} 46.05$ \\
\hline Toth valley & $32^{\circ} 40^{\prime} 18.17$ & $077^{\circ} 11^{\prime} 52.72$ \\
\hline Toth valley & $32^{\circ} 41^{\prime} 44.22$ & $077^{\circ} 13^{\prime} 21.33$ \\
\hline Toth valley & $32^{\circ} 44^{\prime} 44.61$ & $077^{\circ} 15^{\prime} 10.86$ \\
\hline Toth valley & $32^{\circ} 47^{\prime} 23.14$ & $077^{\circ} 17^{\prime} 18.31$ \\
\hline Toth valley & $32^{\circ} 47^{\prime} 28.51$ & $077^{\circ} 19^{\prime} 38.47$ \\
\hline Toth valley & $32^{\circ} 47^{\prime} 08.13$ & $077^{\circ} 21^{\prime} 17.92$ \\
\hline Toth valley & $32^{\circ} 45^{\prime} 48.47$ & $077^{\circ} 23^{\prime} 57.20$ \\
\hline Toth valley & $32^{\circ} 45^{\prime} 22.09$ & $077^{\circ} 24^{\prime} 47.14$ \\
\hline Toth valley & $32^{\circ} 47^{\prime} 13.00$ & $077^{\circ} 20^{\prime} 54.80$ \\
\hline Toth valley & $32^{\circ} 47^{\prime} 31.36$ & $077^{\circ} 17^{\prime} 47.06$ \\
\hline Toth valley & $32^{\circ} 46^{\prime} 32.72$ & $077^{\circ} 18^{\prime} 44.18$ \\
\hline Toth valley & $32^{\circ} 30^{\prime} 59.55$ & $077^{\circ} 58^{\prime} 50.49$ \\
\hline Toth valley & $32^{\circ} 30^{\prime} 33.37$ & $077^{\circ} 00^{\prime} 24.84$ \\
\hline Toth valley & $32^{\circ} 30^{\prime} 15.66$ & $077^{\circ} 03^{\prime} 00.17$ \\
\hline Toth valley & $32^{\circ} 29^{\prime} 05.85$ & $077^{\circ} 06^{\prime} 36.39$ \\
\hline Teenath valley & $32^{\circ} 28^{\prime} 34.40$ & $077^{\circ} 07^{\prime} 37.70$ \\
\hline Teenath valley & $32^{\circ} 25^{\prime} 00.71$ & $077^{\circ} 13^{\prime} 58.93$ \\
\hline Teenath valley & $32^{\circ} 36^{\prime} 59.96$ & $077^{\circ} 53^{\prime} 44.96$ \\
\hline Teenath valley & $32^{\circ} 36^{\prime} 44.79$ & $077^{\circ} 54^{\prime} 54.60$ \\
\hline
\end{tabular}

be accounted. Topographic information such as altitude and location was recorded using GPS.

Reconnaissance survey was initiated in the THR of Lahaul and Spiti district. Fourteen sampling sites falling under different villages (Guling, Kungri, Kaza, Kee, Kibber, Sagnam, Telling, Mudh, Tabo) in Spiti valley (Figure 1 and Table 1), and 35 sampling sites in four valleys (Pattan Valley, Miyar Valley, Toth Valley and Teenath Valley) in Lahaul region (Figure 1 and Table 1) were selected for insect sampling and capacity-building programmes on pollinators conservation and awareness programmes for local communities. The THR is a highaltitude, dry area with rugged mountainous landscape and open plains north of the Himalaya. The local communities follow a traditional agro-pastoralist and nomadic, semi-nomadic and settled village culture. Livestock grazing and associated use of pasture lands has an important ecological history and is a common practice of land use.

Table 2. List of Hymenoptera from Lahaul and Spiti

\begin{tabular}{|c|c|}
\hline Family & Species \\
\hline Andrenidae & Andrina flavipes \\
\hline \multirow[t]{20}{*}{ Apidae } & Anthophora sp. 1 \\
\hline & Amegilla sp. 1 \\
\hline & Anthophora sp. 2 \\
\hline & Anthophora sp. 3 \\
\hline & Anthophora sp. 4 \\
\hline & Anthophora confusa \\
\hline & Apis dorsata \\
\hline & Bombus agrorum \\
\hline & Bombus asiaticus \\
\hline & Bombus haemorrhoidalis \\
\hline & Bombus rufofasciatus \\
\hline & Bombus subtypicus \\
\hline & Bombus tunicatus \\
\hline & Ceratina hieroglyphica \\
\hline & Tetralonia hungarica \\
\hline & Apis melifera \\
\hline & Eucera parvicornis \\
\hline & Eucera clypeta \\
\hline & Xylocopa fenestrata \\
\hline & Xylocopa sp. 1 \\
\hline \multirow[t]{2}{*}{ Chrysididae } & Chrysis angustata \\
\hline & Chrysis sp. 1. \\
\hline Scoliidae & Elis fimbreata \\
\hline Vespidae & Eumenes bengalense \\
\hline \multirow[t]{9}{*}{ Halictidae } & Halictus kessaleri \\
\hline & Sphecodes rubicundus \\
\hline & Halictus pallens \\
\hline & Halictus sp. 1 \\
\hline & Halictidae sp. 1 \\
\hline & Halictidae sp. 2 \\
\hline & Jetraponica trincta \\
\hline & Halictus scaliosa \\
\hline & Halictus mulachurus \\
\hline \multirow[t]{5}{*}{ Megachilidae } & Megachile maritima \\
\hline & Megachile sp. 1 \\
\hline & Megachile sp. 2 \\
\hline & Megachile sp. 3 \\
\hline & Megachile sp. 4 \\
\hline
\end{tabular}




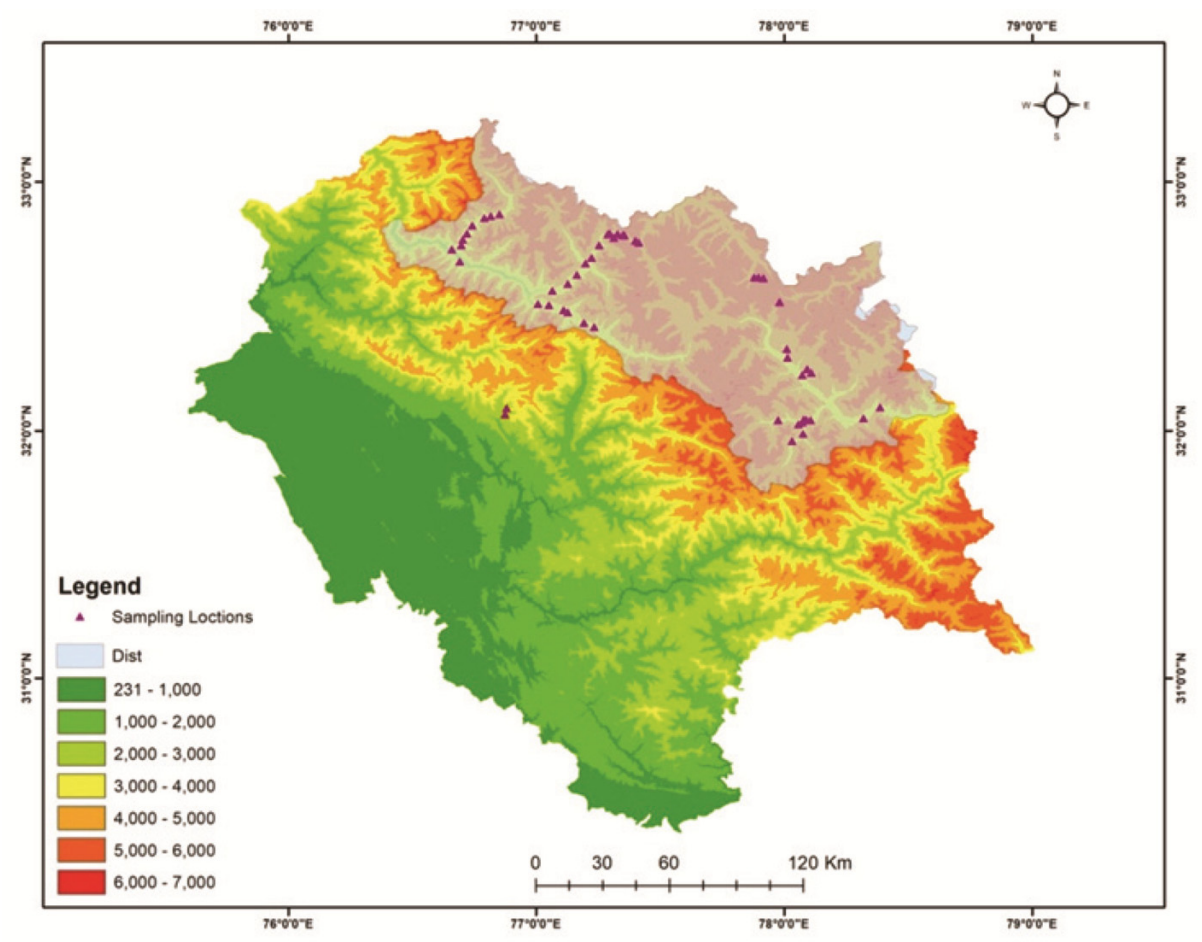

Figure 1. Study sites in Himachal Pradesh, India.

Table 3. List of Lepidoptera from Lahaul and Spiti

\begin{tabular}{lll}
\hline Family & \multicolumn{1}{c}{ Species } & \multicolumn{1}{c}{ Common name } \\
\hline Lycaenidae & Albulina chrysopis & Golden green underwing \\
& Lycaena phlaeas & Common copper \\
& Heliphorus bakeri & Western blue sapphire \\
& Spindasis nipalicus & Sliver grey silverline \\
& Albulina omphisa & Dusky green underwing \\
Nymphalidae & Issoria isaaea & Queen of Spain butterfly \\
& Aulocera swaha & Common satyr \\
& Vanessa indica & Indian red admiral \\
& Neptis hylas & Common sailor \\
& Danus chrysippus & Plain tiger \\
& Junonia lemonias & Lemon pansy \\
& Junonia iphita & Chocolate pansy \\
& Pontia daplidice & Bath white \\
& Pieris canidia & Indian cabbage white \\
Pieris canidia & Common Indian cabbage \\
& Colias erate & Pale clouded yellow \\
Eurema hecabe & Common grass yellow \\
& Pareronia hippia & Common wanderer \\
Delias belladonna & Hill Jezebel \\
Choaspes benjaminii & Indian awlking \\
Celaenorrhinus pyrra & Double spotted flat \\
& Pelopides sinensis & Chinese swift \\
\hline &
\end{tabular}

The study area consists of small fragmented villages in the hilly region at various altitudes. The major occupation in this region is farming and is entirely dependent on fruit and vegetable farming as a cash crop. Crop cultivation is also done at the secondary level; the orchards consist of apple trees, plum, peach, pear, apricot, etc. and vegetables like cauliflower, cabbage, pea, potato, etc.
A total of 61 species of insect pollinators have been recorded from the agro-ecosystem and natural forest consisting of order Hymenoptera (39 species) (Table 2) and Lepidoptera (22 species) (Table 3 ). Solitary bees were reported to be the most diverse group of Hymenoptera. Citizen science approach and capacity building were the major tools for enhancing awareness on insect pollinators and their conservation. Hands-on trainings have been organized for youth for a primary understanding of insect pollinators.

The prevalence of monocultures, cash-crop farming and the inappropriate use of insecticides has been observed in the study. Capacity building and hands on training programmes were organized for all stakeholders (frontline staff of Forest Department/village youth/organizations of local communities). A total of 279 beneficiaries participated in the exercise. Group discussions and meetings were conducted for local communities. Lectures on conservation of insect pollinators were delivered to youth and school children. A total of 362 children participated in the exercise. A number of initiatives have been developed, innovative approaches and curriculum material, which can be used as a basis for scaling-up the capacity building to manage pollination services. Capacity building of local communities, youth, school children and baseline agencies has been achieved through workshops, conservation awareness programme and hands-on trainings and workshops have been organized for the conservation of insect pollinators in selected villages of the region. To begin with, village-level biodiversity groups 

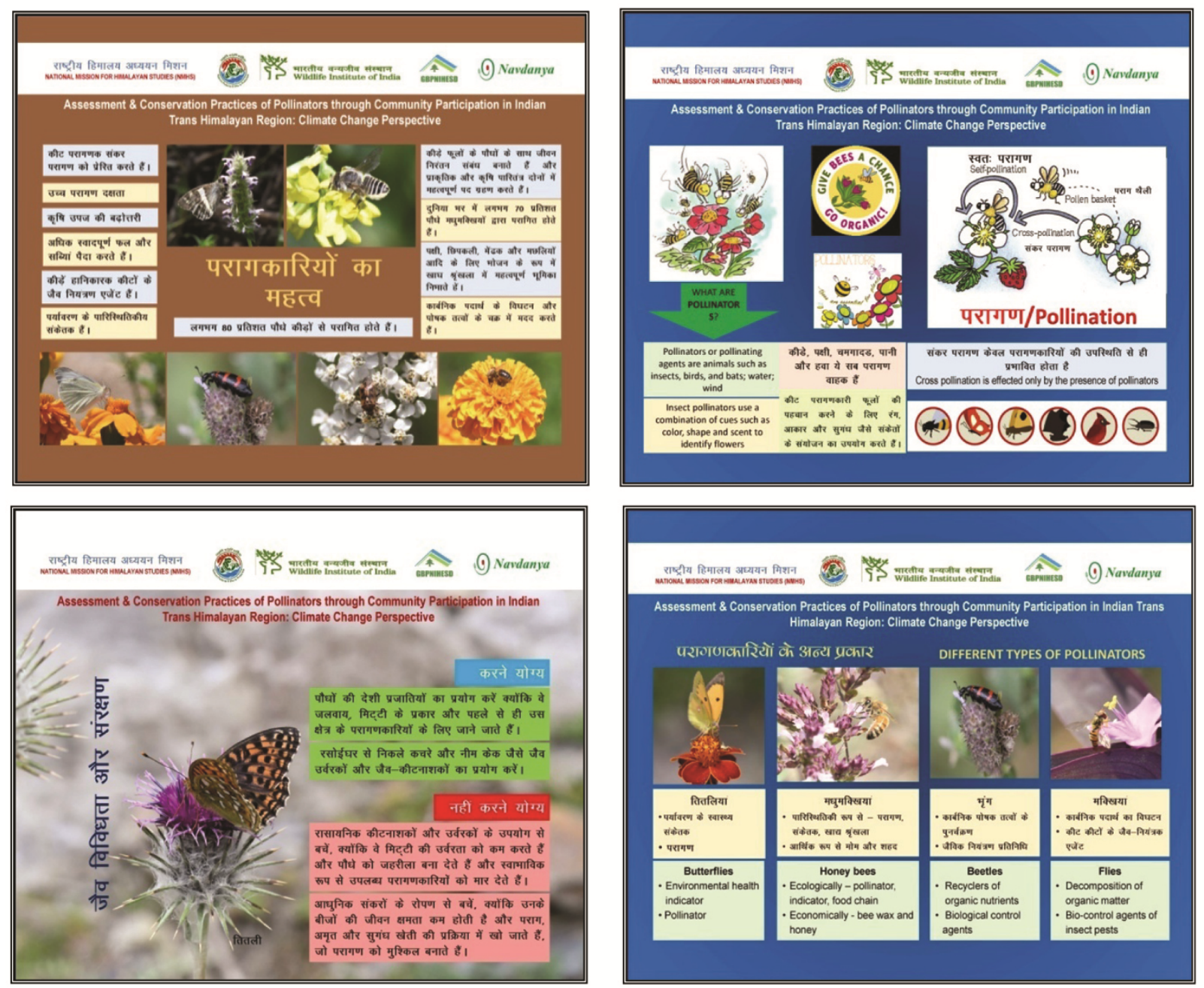

Figure 2. Pamphlets on the conservation of insect pollinators.

were organized in the study villages to sensitize regarding the mitigation of land-use changes, climate change and mitigation measures adopted by the communities. Exercise developed linkages between communities and natural resources of poor rural households. Publicity material on the conservation of insect pollinators was prepared as bilingual pamphlets and distributed (Figure 2).

Pollination is an example of a tangible ecosystem service with direct consequences for human food production, as well as indirect consequences through provision of many other ecosystem services ${ }^{7-10}$. Therefore, maintenance of pollinators and pollination services in agricultural areas where such services are required is of utmost importance. In this region, insecticides are commonly used as sprays and seed treatments. Organic farming which traditionally uses less agro-chemicals than conventional farming has been shown to be beneficial for pollinators, insect pollinated plants and pollination services to both crops and wild species. Increasing cash-crop farming based on monocultures in this region has contributed to reduction in the diversity of plants that provide food for pollinators, which ultimately leads to a decline in insect pollinators diversity. A scientific database has been generated from this study which will be helpful to assess the impact of shifting land-use pattern. Also, changing land-use patterns are closely associated with the socioeconomic conditions, which is a major concern for conservationist and policy makers. Species-level studies could resolve and provide a strong foundation for such policy-making decisions.

In the past, mountain farmers grew a variety of crops which bloomed at different times of the year and provided food for a number of natural insect pollinators. So the diversification of agriculture could be an excellent resolution. Economic incentives to farmers could be effective towards pollinators conservation. This study provides a scientific database for effective land-use management, and insights for future conservation and management planning which will help to set priority areas for habitat improvement or restrict areas from further deterioration. Heterogeneity of habitats within farmlands can be beneficial for biodiversity, and more heterogeneous 
landscapes provide benefits for both butterflies and bumble bees. This can be achieved by the maintenance of field margins and poly culture. Less intensively managed farming systems, especially those with less pesticide use, are generally more beneficial for pollinators and pollination. Workshops and training programmes are necessary for the empowerment of local communities, youth and base line agencies. This tool also helps in planning process for adopting specific strategies and prioritizing insect pollinator conservation efforts.

1. Goulson, D., Lye, G. C. and Darvill, B., Decline and conservation of bumble bees. Annu. Rev. Entomol., 2008, 53(1), 191-208; http://doi.org/10.1146/annurev.ento.53.103106.093454.

2. Yoshihara, Y., Chimeddorj, B., Buuveibaatar, B., Lhagvasuren, B. and Takatsuki, S., Effects of livestock grazing on pollination on a steppe in eastern Mongolia. Biol. Conserv., 2008, 141(9), 23762386; http://doi.org/10.1016/j.biocon.2008.07.004.

3. Potts, S. G., Biesmeijer, J. C., Kremen, C., Neumann, P., Schweiger, O. and Kunin, W. E., Global pollinator declines: trends, impacts and drivers. Trends Ecol. Evol., 2010, 25(6), 345353; http://doi.org/10.1016/j.tree.2010.01.007.

4. Allen-Wardell, G., Bernhardt, P., Bitner, R., Burquez, A., Buchmann, S. L., Cane, J. and Medellin-Morales, S., The potential consequences of pollinator declines on the conservation of biodiversity and stability of fruit crop yields. Conservation Biology, 1998, 12(1), 8-17; http://doi.org/10.2307/2387457.

5. Aguirre-Gutierrez, J. et al., Susceptibility of pollinators to ongoing landscape changes depends on landscape history. Divers. Distrib.. 2015, 21(10), 1129-1140.
6. McKinney, M. L., High rates of extinction and threat in poorly studied taxa. Conserv. Biol., 1999, 13(6), 1273-1281.

7. Kremen, C., Williams, N. M. and Thorp, R. W., Crop pollination from native bees at risk from agricultural intensification. Proc. Natl. Acad. Sci. USA, 2002, 99(26), 16812-16816; http://doi.org/ 10.1073/pnas.2624-13599.

8. Kremen, C., Williams, N. M., Aizen, M. A., Gemmill-Herren, B., LeBuhn, G., Minckley, R. and Ricketts, T. H., Pollination and other ecosystem services produced by mobile organisms: a conceptual framework for the effects of land-use change. Ecol. Lett., 2007, 10(4), 299-314; http://doi.org/10.1111/j.1461-0248. 2007.01018.x.

9. Ashman, T.-L., Knight, T. M., Steets, J. A., Amarasekare, P., Burd, M., Campbell, D. R., and Wilson, W. G., Concepts and sythesis emphasizing new ideas to stimulate research in ecology pollen limitation of plant reproduction: ecological and evolutionary causes and consequences. Ecology, 2004, 85(9), 2408-2421; http://doi.org/10.1890/03-8024.

10. Gleiciani, B. P.-R. and Maria, J. O. C., Aspects of landscape and pollinators - what is important to bee conservation. Diversity, 2014, 6(1), 158-175.

ACKNOWLEDGEMENTS. We thank the Ministry of Environment, Forest \& Climate Change, Government of India and G.B. Pant National Institute of Himalayan Environment and Sustainable Development, Almora for financial support. We also thank the Himachal Pradesh Forest Department for providing logistic support and the necessary permission to conduct this study in the Lahaul and Spiti district and the Director and Dean, Wildlife Institute of India, Dehradun for encouragement and guidance.

doi: $10.18520 / \mathrm{cs} / \mathrm{v} 120 / \mathrm{i} 5 / 883-887$ 